SVU- International Journal of Veterinary Sciences, 2 (1): 68-74, 2019.

Print ISSN: 2535-1826

\title{
Nutritive Value of The Dromedary Camel Meat
}

\section{Hassan A. Abdel-Raheem ${ }^{1 *}$, H. Y. Ahmed ${ }^{2}$, Sh. M. S. Abd-Allah², M. A. A. Abdel-Rasoul2}

${ }^{1}$ Department of Nutrition and Clinical Nutrition, Faculty of Vetrinary Medicine, Assiut University, Assiut, Egypt, ${ }^{2}$ Department of Food Hygiene, Faculty of Veterinary Medicine, Assiut University, Assiut, Egypt.

\section{Abstract}

The current study was conducted to spotlight on the nutritive value of the dromedary camel meat from different ages in Egypt. A total of 50 samples were randomly collected over a period of 10 months from the hindquarter (glutobicepis) muscle of male camel carcasses slaughtered at Assiut and Sharkia Governorates. The samples were divided into two groups according to the age: Group "A" for young age (1 $\leq 5$ years) and Group "B" for old ages (5-8 years). All samples were subjected to a proximate analysis (moisture, protein, fat, ash, and carbohydrate). Only 16 samples from each age were analyzed for some minerals content ( $\mathrm{Ca}, \mathrm{Fe}, \mathrm{K}, \mathrm{P}, \mathrm{Na}$, and $\mathrm{Mg}$ ) and for cholesterol, caloric value and conjugated linoleic acid (CLA) contents. The statistical analysis of the results declared the presence of a significant increase $(p<0.01)$ in fat, ash, carbohydrate, energy, calcium, phosphorus, magnesium, iron, cholesterol and conjugated linoleic acid contents of the camel meat samples with an increasing age. Camel meat from different ages has high nutritive value and it contains considerable amount of protein, which is nearly similar or sometimes higher than other red meat. Pointing to cholesterol and conjugated linoleic acid (CLA) content of camel meat, the obtained mean values in young and old ages were $31.11,3.19$ and 50.63, $5.99 \mathrm{mg} / 100 \mathrm{gm}$ fat, respectively. In conclusion, meat from young camels could be healthier due to its lower fat and cholesterol content.

Keywords: Camel meat, Cholesterol, Linoleic acid, Nutritive value.

DOI: $10.21608 / \mathrm{svu} .2019 .9670 .1006$

Received: February 14, $2019 \quad$ Accepted: February 28, 2019 Published: March 9, 2019

*Corresponding Author: Hassan Abas Abdel-Raheem E-mail: hassan16_99@yahoo.com

Citation: Abdel-Raheem et al., Nutritive value of the dromedary camel meat. SVU-IJVS 2019, 1 (2): 68-74.

Copyright: (C) Abdel-Raheem et al. This is an open access article distributed under the terms of the creative common attribution license, which permits unrestricted use, distribution and reproduction in any medium provided the original author and source are created.

Competing interest: The authors have declared that no competing interest exists. 


\section{Introduction}

The camel is likely to produce animal protein at comparatively low cost in the arid zones based on feeds and fodder that are generally not utilized by other domestic species (Tandon et al., 1988). Economic analysis shows that, camel meat has low wholesale and retail prices (Kadim et al., 2014). A considerable number of camels are managed and bred for slaughtering in the near East and Northern Africa as well as for export to Somalia, Saudi Arabia, Egypt, and the Gulf states (FAO, 2011). The protein content of the camel meat is significantly greater and intramuscular fat is significantly lower than veal (Kadim et al., 2008). The amount of mineral elements in ash and protein content in camel meat are reported to be similar to beef. However, the Najdi-camel meat contains significantly less fat and higher moisture than beef (Dawood and Alkanhal 1995). From healthy and nutritive value view, camel meat is good of choice that it contains high quality protein and they produce carcasses with less fat with fewer calories as well as having less levels of cholesterol in fat than other animal meats (Al-Ani, 2004). Therefore, it is wrongly believed that camel meat to be low in nutritive value and quality than other types of meats (Babiker and Yousif, 1987). Cholesterol is the main sterol present in animal tissues (mainly adipose tissues and fat in meat tissue) which is considered as essential components of cell membrane and can be stored as cholesterol esters in lipid droplets (Dessi and Batetta, 2003). Cholesterol has an essential role in lipid metabolism and other vital processes inside the body while high amount of cholesterol leads to adverse effect on consumer health. Conjugated linoleic acid (CLA) and its isomers are considered as a good not bad trans fatty acids which has many health benefits. CLA are biologically highly active compounds that have several healthy beneficial properties including antitumor, anti-obese, anti-atherogenic and anti-diabetic activities. The molecules have been shown to prevent the onset of hypertension. Age is considered a main factor, which affects the composition and quality of camel meat especially from young ones, which contains low fat with low cholesterol as well as being a good source of high-quality protein and minerals. The favorable and suitable age for slaughtering ranges from $1-4$ years (Abuheif et al., 1990). In Egypt, camel meat is still one of the few meats that have not been chemically studied in detail as well data on the nutritional value of camel meat are very limited particularly in Upper Egypt. Therefore, the present study was planned to determine the approximate chemical composition of camel meat slaughtered at different ages. In addition, caloric value was calculated.

\section{Materials and Methods}

\section{Sampling:}

Fifty meat samples were collected from hindquarter (gluteobiceps muscle) of male camel carcasses (one humped Arabian camel) slaughtered at different ages. The samples were collected randomly over a period of 10 months from both Banny Addey village, Assiut Governorate and from Bilbeis city, Sharkia Governorate. About $250-500$ gm of the fresh meat was taken from each carcass (purchased from meat markets) within $3 \mathrm{hrs}$ post slaughter. The samples were divided into two groups according to the age: group A (25 samples) with age ranged from 1 to $\leq 5$ years old and group B (25 samples) with age ranged from 5 to 8 years old.

The samples after purchase were placed in plastic bags, kept in ice tank and 
quickly transported to a laboratory of meat hygiene section, Department of Food Hygiene, Faculty of Veterinary Medicine, Assiut University for further preparation and analysis.

\section{I.1. Preparation of samples:}

Sample preparation was carried out according to (Kadim et al., 2009). The collected samples were kept in chilling $\left(4^{\circ} \mathrm{C}\right)$ for 24 - 48 hours before further preparation. Then-after most of visible fat, tendon and connective tissue were removed. The samples were well minced through mincing machine, well homogenized using stomacher machine, and kept frozen $\left(-10^{\circ} \mathrm{C}\right.$ at least). Chemical analysis was not delayed, to avoid any chemical and enzymatic changes.

\section{Proximate chemical analysis:}

The prepared meat samples were analyzed for moisture, crude protein, fat, ash, and carbohydrates contents. The samples were analyzed in duplicates. The methods adopted according to AOAC (2000).

III. Calculation of energy value (Merrill and Watt, 1973):

The energy value of camel meat was calculated according to the following equation:

Energy value $(\mathrm{kcal} / 100 \mathrm{~g})=($ Protein $\% \mathrm{X}$ 4) + (Fat \% X 9) + (Carbohydrate \% X 4).

\section{Estimation of some macro and micro essential minerals:}

The iron, magnesium and potassium as well as sodium, calcium and phosphorus contents of the samples were estimated. Inductively Coupled Plasma Optical Emission Spectrometer (ICP-OES 6200, Italy) was used for $\mathrm{Ca}$, magnesium, and iron, while Flame Photometer (Jenway PFP-7, UK) was used for $\mathrm{Na}$ and $\mathrm{K}$ and
Spectrophotometer (Unico 2100 UV, USA) for phosphorus.

$V$. Determination of cholesterol in camel meat tissues (Pasin et al., 1998):

Enzymatic determination using procedures of diagnostic cholesterol reagent (CHOD-PAP, Spectrum, S.A.E.) was applied.

VI. Determination of conjugated linoleic acid (CLA) Cis9-trans11 isomer by Thermo Fourier Transforms Infrared Spectrometer (FT-IR) (AOCS, 2009):

FT-IR IS10 instrument (Nicolet Thermo Scintific Company U.S.A), Department of Chemistry (section B), Faculty of Science, Assiut University, was used for determination of Cis9-Trans 11 CLA isomer in the samples.

VII. Statistical Analysis:

Data statistical analysis was performed by SPSS 16.0 statistical software, (2001). Differences among means were determined using T-test.

\section{Results}

The data presented in Table 1 declared significant differences $(\mathrm{P}<0.001)$ in all parameters of proximate analysis. The moisture and crude protein content of camel meat were significantly decreased $(\mathrm{P}<0.01)$ by increasing camel age however the fat and ash content were significantly increased $(\mathrm{P}<0.01)$ by increasing camel age. From results presented in (Table 2) it is obvious that there was a significant increase in gross energy, total cholesterol and CLA contents in examined camel meat by increasing the age of camels. The most interesting finding was the significant increase $(\mathrm{P}<0.01)$ in $\mathrm{Ca}, \mathrm{Mg}, \mathrm{Fe}$ and $\mathrm{P}$ contents of camel meat by increasing the age of camels (Table 3). However, no significant difference $(\mathrm{P}>0.05)$ was observed between the mean values of potassium and sodium contents in young and old ages camel meat. 
Table 1: Mean values of the proximate chemical analysis of the examined camel meat (\% on fresh basis).

\begin{tabular}{ccccccc}
\hline \multirow{2}{*}{ Group } & \multirow{2}{*}{ Age } & \multicolumn{5}{c}{ Proximate analysis* } \\
\cline { 3 - 7 } & & Moisture & Protein & Fat & Ash & Carbohydrate \\
\hline A & $\mathbf{1} \leq \mathbf{5}$ & $76.83 \pm 0.08^{\mathrm{a}}$ & $21.13 \pm 0.04^{\mathrm{a}}$ & $1.19 \pm 0.07^{\mathrm{b}}$ & $0.80 \pm 0.04^{\mathrm{b}}$ & $0.05 \pm 0.01^{\mathrm{b}}$ \\
B & $\mathbf{5 - 8}$ & $74.90 \pm 0.15^{\mathrm{b}}$ & $20.46 \pm 0.09^{\mathrm{b}}$ & $2.76 \pm 0.08^{\mathrm{a}}$ & $1.48 \pm 0.04^{\mathrm{a}}$ & $0.4 \pm 0.03^{\mathrm{a}}$ \\
\hline
\end{tabular}

Means in the same column with different superscript are significantly different $(\mathrm{P}<0.01)$.

Table 2: Descriptive statistics of energy, cholesterol and CLA contents of the examined camel meat:

\begin{tabular}{lcccccccc}
\hline & Group & $\begin{array}{c}\text { Samples } \\
\text { number }\end{array}$ & $\begin{array}{c}\text { Age } \\
(\text { year })\end{array}$ & Min & Max & Mean & SE & $\begin{array}{c}\text { P. } \\
\text { value }\end{array}$ \\
\hline $\begin{array}{l}\text { Gross energy, } \\
\text { Kcal/100gm }\end{array}$ & A & 25 & $1 \leq 5$ & 90.84 & 99.87 & $\mathbf{9 5 . 4 4}^{\mathbf{b}}$ & 0.55 & \\
\hline $\begin{array}{l}\text { Total } \\
\text { cholesterol, } \\
\text { mg/100gm }\end{array}$ & B & 25 & $5-8$ & 102.41 & 118.92 & $\mathbf{1 0 8 . 4 1}^{\mathbf{a}}$ & 0.88 & $0.001^{*}$ \\
\hline $\begin{array}{l}\text { Conjugated } \\
\text { linoleic acid } \\
\begin{array}{l}\text { CLA }) \\
\text { mg/100g }\end{array}\end{array}$ & A & $16^{\#}$ & $1 \leq 5$ & 14.54 & 50.13 & $\mathbf{3 1 . 1 1}^{\mathbf{b}}$ & 2.88 & \\
\hline
\end{tabular}

Means in the same column for each variable with different superscript are significantly different $(\mathrm{P}<0.001)$.

${ }^{\#}$ Sixteen representative random samples out of 25 total samples were used in these two analyses of total cholesterol (mg/100gm), and CLA (mg/100g) because of financial reason.

Table 3: Mean values of some macro and micro elements $(\mathrm{mg} / 100 \mathrm{~g})$ of the examined camel meat samples (Mean $\pm \mathrm{SE}$ ).

\begin{tabular}{cccccccc}
\hline \multirow{2}{*}{ Group } & \multirow{2}{*}{ Age } & \multicolumn{6}{c}{ Elements* $^{*}$} \\
\cline { 2 - 8 } & $\mathbf{C a}$ & $\mathbf{M g}$ & $\mathbf{F e}$ & $\mathbf{K}$ & $\mathbf{P}$ & $\mathbf{N a}$ \\
\hline \multirow{2}{*}{$\mathbf{A}$} & $1 \leq 5$ & $\begin{array}{c}14.24 \pm \\
0.75^{\mathrm{b}}\end{array}$ & $15.78 \pm 0.47^{\mathrm{b}}$ & $2.16 \pm 0.13^{\mathrm{b}}$ & $279.34 \pm 15.24^{\mathrm{a}}$ & $114.61 \pm 6.03^{\mathrm{b}}$ & $94.72 \pm 7.06^{\mathrm{a}}$ \\
\hline \multirow{2}{*}{ B } & $5-8$ & $24.39 \pm 1.45^{\mathrm{a}}$ & $19.31 \pm 0.79^{\mathrm{a}}$ & $5.50 \pm 0.41^{\mathrm{a}}$ & $298.32 \pm 11.25^{\mathrm{a}}$ & $155.61 \pm 6.03^{\mathrm{a}}$ & $107.5 \pm 9.31^{\mathrm{a}}$
\end{tabular}

Means in the same column with different superscript are significantly different $(\mathrm{P}<0.001)$.

\section{Discussion}

Dromedary camel meat has both nutritional and healthy values as most researchers reported that camel meat contains high amount of protein with high biological value, high minerals content, high polyunsaturated fatty acids, with low intra-muscular fat content than other red 
meats and low cholesterol content and low caloric value (Kadim et al., 2006, 2008; Alamin et al., 2014). Proximate analysis revealed that both moisture and protein content decreased by increasing camel age, while fat, ash and carbohydrate contents increased. The decrease in protein content by increasing camel age was consistent with the finding of earlier studies (AlShabib and Abu-Tarboush, 2004; Kadim et al., 2006, Saleh (2010), Raiymbck et al., 2013; Kadim et al., 2013). In contrast, Dawood and Al-Kanhal (1995), Mahmud et al. (2011), and Muhammed and Abubaker (2011) reported that protein content of camel meat was lower in old age camels in comparison with young camels (18.88vs 20.07, 20.1 vs $20.27,18.57$ vs $19.25 \%$, respectively). On the contrary, to that result EL-Mossalami et al. (1995) recorded higher values of protein $\%$ in his study ( $22.02 \%$ and $24.93 \%$, respectively). Lower protein values $(18.8,19.52$, and $18.5 \%$, respectively) were observed for old age camels. Calculated energy content of the examined samples significantly increased with ages. This result was not agreeing with those obtained by Soltanizadeh et al. (2010) who reported higher caloric value $120.2 \mathrm{kcal} / 100 \mathrm{gm}$ in young age camel. For old age camels the current results were closely similar to those found by Bieklen et al. (2007) $108.03 \mathrm{kcal} / 100 \mathrm{gm}$ but lower than those reported by Shahin (2006) $144 \mathrm{kcal} / 100$ gm. The increase in cholesterol content by increasing $g$ the age of camels consistent with those Farah and Fisher (2004) and Kadim et al. (2008) for old age camels. Cholesterol and conjugated linoleic acid (CLA) contents in camel meat significantly increased with age. Although cholesterol increases with age, however its amount is still lower than other red meats. AbuTarbush and Dawood (1993) did the early investigation of cholesterol content in camel meat and Kadim et al. (2013 and
2014) who noted that cholesterol content in camel meat increases with an increasing of animal age, and this agree with the obtained results. The detected camel meat content of conjugated linoleic acid (CLA) particularly cis9-tran 11 was nearly similar to another ruminants' meat. The values for calories, cholesterol and CLA of camel meat. CLA of young age camel was nearly similar to that reported by Shibani et al. (2011). For old age camel, Beilken et al. (2007) reported close similar value. Effect of animal age on CLA content in camel meat was previously observed by Fritsche and Fritsche (1998), Raes et al. (2004), Dhiman et al. (2005), De la torre et al. (2006) and Barton et al. (2011), also they noted that diet, breed and seasonal variation could affect CLA content in ruminant's meat.

The higher calcium, magnesium, iron and phosphorus contents of camel meat in old camel meat than in young one was in agreement with the finding of Kadim et al. (2008 and 2009) who observed that camel meat has high $\mathrm{Na}$, Fe and $\mathrm{Ca}$ content recorded similar results. It has been established that potassium content in camel meat is the highest among other mineral elements followed by in descending order, phosphorus, sodium, magnesium and calcium (Kadim et al., 2006).

In conclusion, camel meat from different ages had different nutritive value. It contains considerable amount of protein, which is nearly similar or sometimes higher than other red meat. Meat from young camels could be considered as a healthy option because it contains lower fat and cholesterol content.

\section{Conflict of interest statement}

The authors declare that they have no conflict of interest. 
Acknowledgement

The authors wish to acknowledge the support provided by the Department of Animal Nutrition and Clinical Nutrition, and the Department of Food Hygiene, Faculty of Veterinary Medicine, Assiut University, Assiut, Egypt. Special thanks to Dr. Sherief M. Abdel-Raheem for his valuable comments during revising the manuscript.

\section{References}

Abuheif M, Basmaeil SM, Bakkar MN (1990). A standard method for jointing camel carcasses with reference to the effect of slaughter age on carcass characteristics in Najadi Camels I- Wholesale cut weight. Asian-Australian Journal of Animal Science, 3: 97-102.

Abu-Tarboush HM, Dawood, A.S. (1993). Cholesterol and fat contents of animal adipose tissues. Food Chemistry, 46: 89-93.

Alamin SA, Ahmed DA, Ahmed HE (2014). A Comparative study on the chemical composition and cholesterol content of fresh camel, beef and goat meat. Sudan Journal of Science and Technology, 15 (2): $73-80$.

Al-Ani FK (2004). Camel Management and Diseases. ( $1^{\text {st }}$ Eds.), AlShraga printing press and Dar Ammar Book publisher, Amman, Jourdan.

Al-Shabib, NA, Abu-Traboush, HM (2004): Nutritional value and some functional properties of protein in ostrich and camel meat. Arab Journal of Food Nutrition 5, 6-20.

AOAC, Official Methods of Analysis of Association of Analytical Chemist (2000). $17^{\text {th }}$ Ed., AOAC
International, Gaithersburg. MD. USA.

AOCS, Official Method Cd14e-09 (2009). Negative second derivative infrared spectroscopic method for the rapid (5min) determination of total isolated trans-fat. p. 1-6. Available online at: http://www.aocs.org/methods

Babiker SA, Yousif KH (1987). Carcass yield and characteristics of mature male camels of the Sudan. Annual report, Camel Research Unit, University of Khartoum, Sudan. p. 120-124.

Beilken S, Eustace I, Tume R (2007). Composition of new meats: Analysis and nutrient composition of innovative meat industries. Rural Industries Research and Development Corporation, Publication No. 07/036, Australia.

CACIA, Central Australian Camel Industry Association (2006). Comparison of camel and other meats. Alice Spring, Australia.

Dawood A, Alkanhal MA (1995). Nutrient composition of Najdi-camel meat. Meat Science, 39: 71-78.

De La Torre A, Gruffat D, Durand D, Micol D, Peyron A, Scislowski V, Bauchart D (2006). Factors influencing proportion and composition of CLA in beef. Meat Science, 73: 258-268.

Dessi S, Batetta B (2003). Overview intracellular cholesterol homeostasis: old and new players. In: Pani A., Dessi S., (Edts), Cell Growth and Cholesterol Esters. Kluwer Academic/Plenum Publishers, New York. P 1-12.

Dhiman T, Nam S, Ure AL (2005). Factors affecting conjugated linoleic acid content in milk and meat. Critical Reviews in Food Science and Nutrition, 45: 463-482. 
El-mossalami E, Awad Y, Ibrahim A, Diab O (1996). Major chemical constituents of beef, buffalo and camel's meat. Veterinary Medical Journal, Giza 44 (1): 49-53.

FAO Food and Agriculture Organization (2011). FAOSTAT database, United Nation. Available online at:

http://faostat.fao.org/site/339/defa ult.aspx

Farah Z, Fischer A (2004). Milk and meat from the camel: Handbook on products and processing. Vdf Hochschulverlag, AG., Zürich.

Fritsche S, Fritsche J. (1998). Occurrence of CLA isomers in beef. Journal of the American Oil Chemists Society, 75 (10): 1449-1451.

Kadim IT, AI-Hosni Y, Mahgoub O, AIMarzooqi W, Khalaf, Samera K, AI-Sinawi SS H., AI-Lawati, A. M., Al-Amri, I. S. (2009). Effect of low voltage electrical stimulation on post-mortem biochemical and quality characteristics of Longissimus thoracis of Omani Arabian camel (Camelus dromedarius). Meat Science, 82: 77-85.

Kadim IT, Mahgoub O, Mbaga, M. (2014). Potential of camel meat as a nontraditional high-quality source of protein Kadim IT, Mahgoub O, Mbaga M. for human consumption. Animal Frontiers 4 (4):13-17.

Kadim IT, Mahgoub O, AI-Marzooqi W, AI-Zadgali S, Annamali K, Mansour MH (2006). Effect of age on composition and quality of muscle Longissimus thoracis of the Omani Arabian camel (Camelus dromedarius). Meat Science, 73: 619-625.
Kadim IT, Mahgoup O, Al-Marzooqi W (2008). Meat quality and composition of longissimus thoracis from Arabian camel (Camelus dromedarius) and Omani beef: A comparative study. In: First Conference of the International Society of Camelids Research and Development, AIAin, United Arab Emirates. p. 118.

Kadim IT, Mahgoub O, AL-Marzooqi W, Khalaf SK, Raiymbek G. (2013). Composition, quality and healthy aspects of the Dromedary (Camelus dromedarius) and Bacterian (Camelus bacterianus) camel meats. Agricultural and Marine Sciences, 18: 7-24.

Mahmud T, Rehman R, Anwar J., Ali, S., Abbas, A., Salman, M. (2011). Minerals and nutritional composition of camel (Camelus dromedaries) meat in Pakistan. Journal of Chemical Society in Pakistan, 33 (6): 835- 838.

Merrill AL, Watt BK (1973). Energy value of foods - basis and derivation. U. S. Dept. Agriculture. Handbook, No. 74:105.

Muhammad BF, Abubakar FM (2011). Chemical composition of raw and cooked camel (Camelus dromedarius) meat cuts. Savannah Journal of Agriculture, 6 (2): 32-36.

Mulvihill B. (2001). Ruminant meat as a source of conjugated linoleic acid (CLA). British Nutrition Foundation Nutrition Bulletin, 26: 295-299.

Nagao K, Yanagita T (2005). Conjugated fatty acids in food and their health benefits. J. Bioscience and Bioengineering, 100 (2): 152-157. 